\title{
Effect of geographical directions, height and the color of yellow traps in capture of Mediterranean fruit fly, Ceratitis capitata (Wiedemann, 1824) in citrus orchards
}

\author{
Amir Hossein TOORANI ${ }^{1}$, Habib ABBASIPOUR ${ }^{2 *}$
}

Received July 27, 2017; accepted November 30, 2017.

Delo je prispelo 27. julija 2017, sprejeto 30. novembra 2017.

\begin{abstract}
Mediterranean fruit fly, Ceratitis capitata (Wiedemann, 1824) (Dip.: Tephritidae) is one of the most destructive agricultural pests in the world. To replace chemical control methods, as well as the timing of the peak population of Mediterranean fruit fly, the yellow sticky vertical traps were used in this study. The research was carried out in some citrus orchards of various cities of Mazandaran province of Iran, during the four months from August to November 2016. To determine the best type of yellow color to trap this fly, four types of yellow colors with measured wavelength of reflection, including the fluorescent yellow $(538 \mathrm{~nm})$, lemon yellow $(574 \mathrm{~nm})$, yellow $(602 \mathrm{~nm})$ and amber yellow $(641 \mathrm{~nm})$, were used. Also, to determine the best geographical direction and appropriate height for installation of yellow cards, four cardinal directions and five different heights of 1, 1.5, 2, 2.5 and $3 \mathrm{~m}$ above ground level were determined and the cards were installed. The results of mean comparison of captured flies in different treatments showed that there are significant differences between all of them. The results indicated that the fluorescent yellow, heights of 1.5 and $2 \mathrm{~m}$, the south direction, and month October had the highest number of capture in yellow cards.
\end{abstract}

Key words: Mediterranean fruit fly; yellow sticky trap; mass trapping; citrus; Iran
IZVLEČEK

\author{
VPLIV NEBESNE LEGE, VIŠINE NAMESTITVE IN \\ BARVE RUMENIH PASTI NA ULOV BRESKOVE \\ MUHE (Ceratitis capitata (Wiedemann, 1824)) V \\ SADOVNJAKIH CITRUSOV
}

Breskova muha (Ceratitis capitata [Wiedemann, 1824], (Dip.: Tephritidae)) je eden od najpomembnejših škodljivcev gojenih rastlin $\mathrm{v}$ svetu. Za nadomestitev kemičnega zatiranja in za ugotavljanje viška populacij breskove muhe so bile $\mathrm{v}$ tej raziskavi uporabljene navpično nameščene rumene, lepljive pasti. Raziskava je potekala v izbranih sadovnjakih citrusov v različnih krajih province Mazandaran v Iranu, v času štirih mesecev, od avgusta do novembra leta 2016. Za določitev najustreznejše rumene barve pasti za lovljenje muh so bili izbrani 4 odtenki rumene barve, vključujoč fluorescentno rumeno $\mathrm{z}$ naslednjimi valovnimi dolžinami odbite svetlobe: fluorescentno rumena $(538 \mathrm{~nm})$, limonino rumena $(574 \mathrm{~nm})$, rumena $(602 \mathrm{~nm})$ in rjavo (smolnato)-rumena $(641 \mathrm{~nm})$. Za določitev najustreznejše nebesne smeri in višine namestitve rumenih plošč so bile izbrane štiri glavne nebesne smeri in pet različnih višin namestitev nad tlemi, in sicer 1, 1,5, 2, 2,5 in $3 \mathrm{~m}$. Izsledki primerjav povprečij ulovljenih muh glede na različne namestitve pasti so pokazali, da so med njimi značilne razlike. Izsledki so pokazali, da se je ujelo največ muh v oktobru na fluorescentno rumene plošče, nameščene od 1,5 in $2 \mathrm{~m}$ nad tlemi, v južni legi.

Ključne besede: breskova muha; rumena lepljiva past; masovno lovljenje; citrus; Iran

\section{INTRODUCTION}

Mediterranean fruit fly (Medfly), Ceratitis capitata (Wiedemann, 1824) (Dip.: Tephritidae) is one of the most important pests of citrus (White \& Elson-Harris, 1992). The damage amount of these pests to fruits is relatively high and sometimes, up to a hundred percent of fruits are infected by the pests (Fimiani, 1989). The pest has been established for about a century in Hawaii and despite persistent and costly eradication efforts, is repeatedly detected in Florida and California (Carey, 1996; Jang, 2007). It is estimated that the cost of each of

1 Postgraduate MSc. Student, Department of Plant Protection, Faculty of Agricultural Sciences, Shahed University, Tehran, Iran

2 Professor, Department of Plant Protection, Faculty of Agricultural Sciences, Shahed University, Tehran, Iran *corresponding author: Habbasipour@yahoo.com 
its previous incursions into the US (eradication and industry loss) ranged from US\$ 300,000 to US\$ $200 \mathrm{M}$ (APHIS, 1992). Medfly outbreaks in California during the past 25 years have cost taxpayers nearly $\$ 500$ million, while the Medfly outbreak in Florida's Tampa Bay region in 1997 resulted in \$25 million spent on eradication, which is significantly less than the cost of potential establishment. It has been estimated that the cost of controlling established Medfly in the State of California alone could range between $\$ 493$ million to $\$ 875$ million, and imposition of trade embargo from Asian countries would result in additional revenue losses of $\$ 564$ million and cost more than 14,000 jobs (Szyniszewska \& Tatem, 2014). The eastern Mediterranean region also experienced substantial losses linked to fruit fly infestations estimated at US\$ 192 M (Enkerlin \& Mumford, 1997). These flies carry the potential of post-harvest diseases such as Alternaria, Penicillium and Botrytis on different products (Cayol et al., 1994). This pest is highly polyphagous, and more than 400 plant species have been reported as hosts for it (USDA, 2012). This pest attacks fruit trees, including apple, apricot, avocado, citrus, guava, nuts, litchi, grapes, mango, papaya, peach, pear, plum, quince, palm, pomegranates and other fruit trees (Pezhman et al., 2010a, b).

In Iran, Mediterranean fruit fly was observed for the first time in 1975 on the peach fruit in the orchards and gardens surrounding Mashhad railway station and then in the orchards and gardens in and around the city of Yazd (Mirsardo et al., 2010). During the years 1975 to 1978, it was reported from around Tehran and the eastern part of Mazandaran province, Iran. Mazandaran province as the latest focus of pest infestation, was cleaned during the years 1980 to 1982 and from that date to 1991, there have been no reports of the presence of pests in these areas (Sabzevari \& Jafari, 1991). Investigation of the geographical distribution of medfly in Mazandaran province in the years 2006-2008, showed that the fly infestation in 2006 was limited to the eastern cities of Mazandaran, which was reached the western regions in 2007 and only, Ramsar city was free of infestation (Mirsardo et al., 2010). In general, according to the results of Gholamian et al. (2013), it seems that the Mediterranean fruit fly can easily spread annually between 10 to $40 \mathrm{~km}$ depending on weather conditions, natural obstacles (forest and hills), and hosts on region and due to infestation of this pest in an area, it can be expected that the population of which will increase there in the following years. Also taking into account the pest population peak in the fall of each year, right control measures can be employed before reaching the pest to its maximum population (Gholamian et al., 2013).
Trap catches are the best means for detection of medfly. Broad studies have been conducted by researchers from different countries on a variety of Mediterranean fruit fly traps and catches (Katsoyannos et al., 1999). Investigations conducted on a variety of catching traps for identifying and tracking the medfly in Egypt showed that the Nadel trap with Trimedlure had attracted the most flies. While McPhail traps with hydrolyzed protein had the highest catches of female flies, and also the McPhail trap with diammonium phosphate had the lowest of attraction the flies (Hashem et al., 1987).

Unfortunately today, chemical pesticides are used for fight and control of pests. The most important dangers of pesticides can be considered as their negative impact on the environment and human health, wildlife, plants and beneficial organisms. One way to control this pest is to use sticky yellow cards (Pezhman et al., 2010a). Various factors such as shape, color, and location can affect the efficiency of traps (Hashem et al., 1987).

Yellow is one of the most influential physical stimuli used in the manufacture of adhesive and McPhail traps, whether in mass trapping or in the monitoring program of pests (Hill \& Hooper, 1984). Sticky trap consists of a yellow rectangular plastic sheet both sides of which is covered by a thin layer of a special glue (Tanglefoot). Due to two-dimensional design and high surface area, these traps are more efficient than Jackson traps and a variety of Mcphail traps in capturing fruit flies (Hill \& Hooper, 1984). In Palestinian, circular trapping around the fruit orchards, was of successful outcomes in controlling the Mediterranean fruit fly (Cohen \& Yuval, 2000). Tracking is an action used to understand the pest activity and make more informed decisions for its management. Care to determine the population dynamics is conducted using special attracting traps and the number of insects trapped by the traps is used to determine the existence and population dynamics of the pest in an area. The results of tracking can be used to determine the potential damage of the pest. In conjunction with the highly mobile insects such as fruit flies, using traps is very effective. Trapping and attractants in any orchard is a method with the least spending of time and effort to track fruit fly population. So as a replacement for chemical control methods and avoid damage to the environment, the present investigation was carried out to evaluate relative efficiency of various yellow color sticky traps at four heights in north, east, south and west directions against citrus fruit fly. This information will be useful in improving monitoring technique and mass trapping of this pest in citrus orchard and more helpful in enhancing integrated pest management programs by developing strong decision making component as sticky trap. 


\section{MATERIALS AND METHODS}

This research was conducted in a number of citrus orchards in Mazandaran province, within four months of the year 2016 (the months of August, September, October and November). Considering that the activity of this flies in citrus orchards of Mazandaran province during these four months is significant and can cause damage in citrus orchards, these months were carefully examined.
The locations of the study were shown in figure 1 . The age of the trees in the orchards was typically between 18 and 20 years and all the trees were mature and productive. Operations of fertilizing, irrigation, pruning and removing weeds took place regularly in these orchards. In 2016, no pesticide was used against pests at the orchards under study. The types of trees of these orchards were Thomson orange, blood orange and Valencia orange and their rootstock was orange.

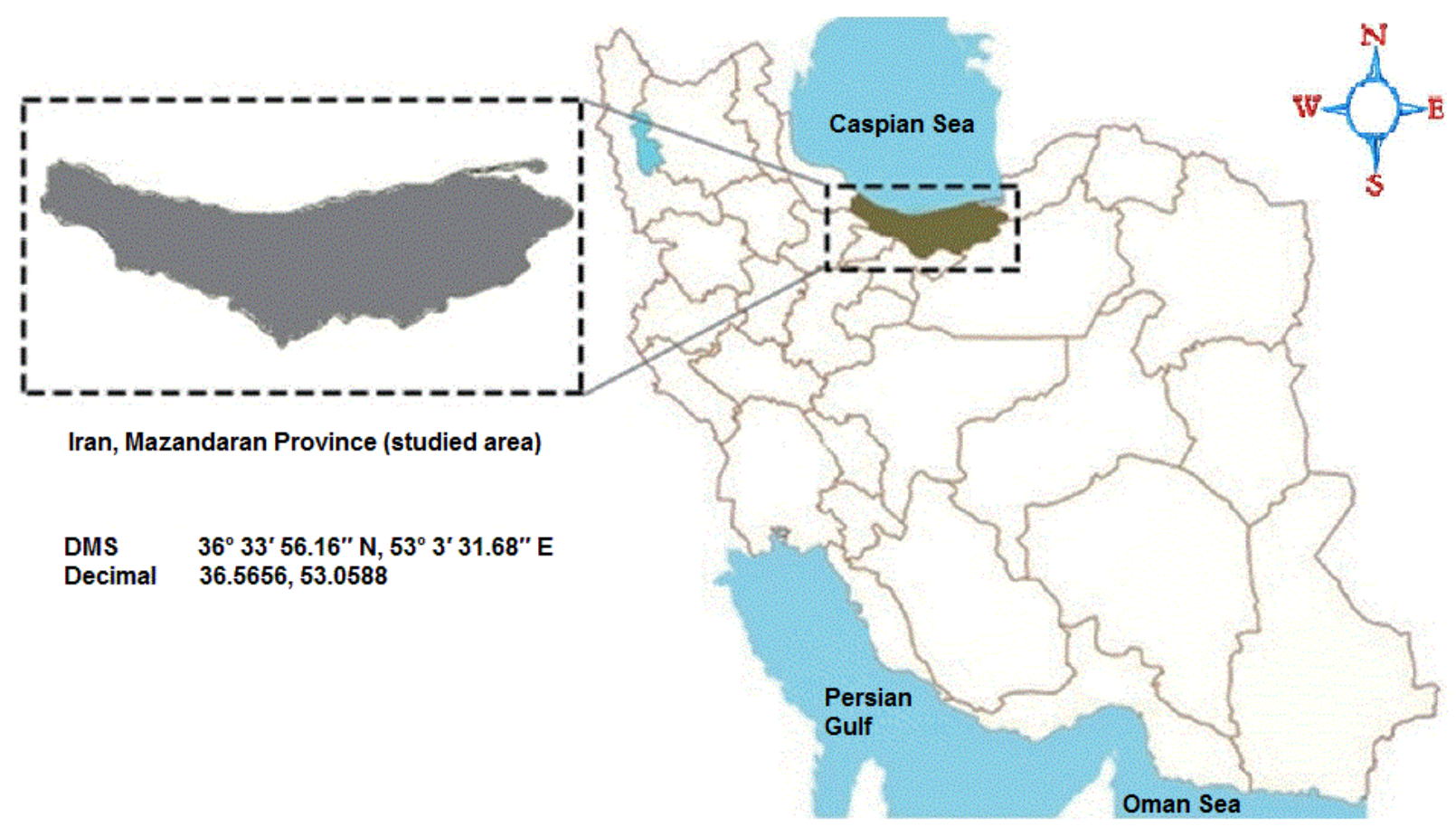

Figure 1: Area of study

To determine the best type of yellow color to trap these flies, four types of traps including lemon yellow sticky trap, amber yellow sticky trap, fluorescent yellow sticky trap, and yellow sticky trap, were used. Yellow sticky cards used in this study, were evaluated in the Nano Institute of Sharif University of Technology by fluorescence spectrometer in order to calculate the wavelength and the percentage of light reflected of each one. These cards included respectively, the fluorescent yellow (538 nm and $2.75 \%$ ), lemon yellow (574 nm and $2.48 \%$ ), yellow (602 $\mathrm{nm}$ and $2.12 \%$ ) and amber yellow (641 nm and $1.16 \%)$.

In addition to the above, to find out the best geographical direction for installing yellow cards, four geographical directions (North, South, East and West) were determined and the cards were installed. Finally, to find out the best height suitable for installation of yellow cards on trees, five different heights $(1,1.5,2$, 2.5 and $3 \mathrm{~m}$ above ground level) were determined using meter and cards were installed.

This study was conducted as a factorial experiment on the basis of randomized completely blocks design in 320 treatments and 3 replications, which in total, a number of 320 trees were selected randomly and yellow sticky cards were installed due to the height, direction and type of special adhesive. The logarithms of the obtained data were analyzed on the basis of the factorial experiment $4 \times 4 \times 4 \times 5$ in a completely randomized design with three replications. In order to prevent the interaction of traps with each other, the distance between them was $25 \mathrm{~m}$. The sticky traps lacked pheromones and on each tree, one trap was installed. 
The yellow cards were of $20 \mathrm{~cm}$ length and $10 \mathrm{~cm}$ width and were tied up to the tree branches using plastic wires in order not to change their position by the wind. Since the quality and performance of the adhesive decrease with the passage of time by the sun and the rain, yellow cards of the experiment were replaced every 15 days. For counting the number of flies captured by yellow cards, a pocket binocular with a magnification of $\times 60$ was used and identification of male and female insects was carried out through their morphological characteristics and the data collected were recorded every 15 days.

\subsection{Data analyses}

After completion of counting, the data were analyzed using the statistical package SPSS version 22. Means comparison was performed using Tukey's HSD test and the corresponding graphs were drawn in Excel.

\section{RESULTS}

The results of ANOVA analysis of data obtained from this study are presented in Table 1 and indicate that except for replicate, there is a significant difference between other treatments in the $5 \%$ level.

Table 1: ANOVA Analysis of data from different treatments capturing the Mediterranean fruit fly, Ceratitis capitata by different kinds of yellow cards

\begin{tabular}{llll}
\hline Source of variations & df & F-value & Sig. \\
\hline Corrected Model & 322 & 120.919 & 0.01 \\
Intercept & 1 & $2.695 \mathrm{E} 4$ & 0.01 \\
Month & 3 & $1.633 \mathrm{E} 3$ & 0.01 \\
Color & 3 & $3.099 \mathrm{E} 3$ & 0.01 \\
Height & 4 & $1.228 \mathrm{E} 3$ & 0.01 \\
Direction & 3 & $1.374 \mathrm{E} 3$ & 0.01 \\
Repetition & 3 & 0.772 & 0.510 \\
height $\times$ direction & 12 & 72.318 & 0.01 \\
month $\times$ height $\times$ direction & 45 & 26.634 & 0.01 \\
month $\times$ color $\times$ height $\times$ direction & 135 & 17.922 & 0.01 \\
month $\times$ color & 9 & 514.198 & 0.01 \\
month $\times$ height & 12 & 93.087 & 0.01 \\
color $\times$ height & 12 & 181.291 & 0.01 \\
color $\times$ direction & 9 & 140.232 & 0.01 \\
month $\times$ color $\times$ height & 36 & 41.817 & 0.01 \\
color $\times$ height $\times$ direction & 36 & 14.650 & 0.01 \\
Error & 957 & & \\
Total & 1280 & & \\
Corrected Total & 1279 & & \\
\hline
\end{tabular}

The results of mean comparison of flies captured in different months, colors, heights and directions showed that there are significant differences between all of them. So that, the highest number of flies were captured in October, and the lowest one in August (13.94 \pm 0.23 and $4.22 \pm 0.21$ per trap, respectively). According to the results of captured flies in males and females which were analyzed separately, compared with each other, the largest number was of male flies in October (7.14 \pm 0.10 ) and the lowest flies captured of female ones in August (2.22 \pm 0.12), respectively. The mean Comparison of number of captured flies by different 
colors showed that the fluorescent yellow color had the highest number of capture $(14.47 \pm 0.31)$ and amber yellow had the lowest catches (1.96 \pm 0.19$)$, respectively. Also, comparing the number of male and female captured by different colors showed that the highest number of male captured by fluorescent yellow $(7.57 \pm 0.18)$ and the lowest number of male captured by Amber yellow (1.02 \pm 0.09$)$, respectively. In comparing the number of captured flies in different heights, the results of Table 2 showed that the height of $1.5 \mathrm{~m}$ had a slight difference with $2 \mathrm{~m}$ and had the maximum number of capture $(12.72 \pm 0.52)$. While at the height of $3 \mathrm{~m}$, the minimum number of flies $(3.75 \pm$ 0.31 ) was captured. Despite the fact that there is a significant difference in the number of flies captured in all different heights, but the results of means comparison for males and females which was carried out separately, indicates that the 1.5 and $2 \mathrm{~m}$ heights, with the highest number in the capture of males and females, were not significantly different from each other, but this was different for other heights. In addition to above explanations, the results of means comparison of the number of flies per bait in different directions, showed that the South and East recorded the highest number of captured flies, which were $12.17 \pm$ 0.44 and $10.92 \pm 0.51$, respectively. In conjunction with the results of comparing the average number of flies captured in males and females, which were carried out separately, it was found that males had the most captures in the South $(6.27 \pm 0.23)$, while the lowest number of males captured $(2.22 \pm 0.16)$ was in the West.

Table 2: Results of number of capturing (mean $\pm \mathrm{SE}$ ) the Mediterranean fruit fly, Ceratitis capitata by different kinds of yellow cards in different treatments

\begin{tabular}{ccccc}
\hline Source of variation & Treatment & Male & Female & Total \\
\hline \multirow{4}{*}{ Month } & August & $2.22 \pm 0.12^{\mathrm{d}}$ & $2.00 \pm 0.08^{\mathrm{d}}$ & $4.22 \pm 0.21^{\mathrm{d}}$ \\
& September & $4.31 \pm 0.08^{\mathrm{b}}$ & $4.13 \pm 0.19^{\mathrm{b}}$ & $8.44 \pm 0.25^{\mathrm{b}}$ \\
& October & $7.14 \pm 0.10^{\mathrm{a}}$ & $6.80 \pm 0.12^{\mathrm{a}}$ & $13.94 \pm 0.23^{\mathrm{a}}$ \\
& November & $3.57 \pm 0.15^{\mathrm{c}}$ & $3.22 \pm 0.15^{\mathrm{c}}$ & $6.79 \pm 0.29^{\mathrm{c}}$ \\
\hline \multirow{4}{*}{ Color } & Fluorescent Yellow & $7.57 \pm 0.18^{\mathrm{a}}$ & $6.89 \pm 0.11^{\mathrm{a}}$ & $14.47 \pm 0.31^{\mathrm{a}}$ \\
& Lemon Yellow & $5.80 \pm 0.07^{\mathrm{b}}$ & $5.67 \pm 0.13^{\mathrm{b}}$ & $11.48 \pm 0.22^{\mathrm{b}}$ \\
& Amber Yellow & $1.02 \pm 0.09^{\mathrm{d}}$ & $0.94 \pm 0.09^{\mathrm{d}}$ & $1.96 \pm 0.19^{\mathrm{d}}$ \\
& Yellow & $2.83 \pm 0.08^{\mathrm{c}}$ & $2.65 \pm 0.13^{\mathrm{c}}$ & $5.49 \pm 0.21^{\mathrm{c}}$ \\
\hline \multirow{5}{*}{ Height } & 1 & $3.12 \pm 0.17^{\mathrm{c}}$ & $2.80 \pm 0.11^{\mathrm{c}}$ & $5.93 \pm 0.29^{\mathrm{d}}$ \\
& 1.5 & $6.54 \pm 0.21^{\mathrm{a}}$ & $6.18 \pm 0.30^{\mathrm{a}}$ & $12.72 \pm 0.52^{\mathrm{a}}$ \\
& 2 & $6.27 \pm 0.23^{\mathrm{a}}$ & $6.05 \pm 0.17^{\mathrm{a}}$ & $12.31 \pm 0.38^{\mathrm{b}}$ \\
& 2.5 & $3.66 \pm 0.14^{\mathrm{b}}$ & $3.37 \pm 0.19^{\mathrm{b}}$ & $7.03 \pm 0.36^{\mathrm{c}}$ \\
& 3 & $1.96 \pm 0.08^{\mathrm{d}}$ & $1.80 \pm 0.21^{\mathrm{d}}$ & $3.75 \pm 0.31^{\mathrm{e}}$ \\
\hline \multirow{5}{*}{ Direction } & North & $3.06 \pm 0.07^{\mathrm{c}}$ & $2.81 \pm 0.13^{\mathrm{c}}$ & $5.87 \pm 0.20^{\mathrm{c}}$ \\
& South & $6.27 \pm 0.23^{\mathrm{a}}$ & $5.90 \pm 0.20^{\mathrm{a}}$ & $12.17 \pm 0.44^{\mathrm{a}}$ \\
& East & $5.69 \pm 0.31^{\mathrm{b}}$ & $5.22 \pm 0.17^{\mathrm{b}}$ & $10.92 \pm 0.51^{\mathrm{b}}$ \\
& West & $2.22 \pm 0.12^{\mathrm{d}}$ & $2.22 \pm 0.16^{\mathrm{d}}$ & $4.44 \pm 0.29^{\mathrm{d}}$ \\
\hline
\end{tabular}

* Similar letter in each column show no significant difference.

According to the correlation observed between months under study with heights, card colors and directions, independent separation of data was carried out between different months (Table 3). ANOVA results showed that there is a significant difference between all variables and total number of males and females. But by sex separation, no significant relationship was found between the color and direction in males in November. In addition, in both males and females in August and November, no significant relationship was between height and direction. Among the other treatments in males and females, like their sum, there was no significant difference and relationship.

Mean comparison results of capture in different directions, on yearly basis, given in Table 4 , show that in total captures in all months, the South and then the East, had the highest rate of capture. Whereas, the North and then the West, had the lowest captures. Also the lowest capture rate for the total population, was in the West $(1.84 \pm 0.35)$ during August and the highest one was for the month of October in the South $(19.85 \pm$ 1.93). In comparing males and females population in different directions, results showed that male insects were dominant in the south in October $(10.19 \pm 0.92)$.

The comparison of males, females and total number of flies captured, separately in different months in Table 5 showed that in August, September and October months, the highest number of male and female captured by fluorescent yellow. But in November, the lemon yellow color has captured the highest number. The lowest 
capture rate was for the female in August and in the amber yellow color $(0.51 \pm 0.07)$, and the highest rate of capture belonged to the male in October and in chartreus yellow color $(14.91 \pm 1.12)$.

The results comparison of different months, by height (Table 6) showed that in all months, height of $1.5 \mathrm{~m}$ had the highest number of capture, except for September, in which the number of females captured in the height of 2 $\mathrm{m}$ was more than the $1.5 \mathrm{~m}$ height, while the differences were not significant. The lowest number of insects captured between male and female flies was for female insects in September and in height of $3 \mathrm{~m}(0.66 \pm 0.13)$ and the highest number of females was captured in November at the height of $1.5 \mathrm{~m}(10.81 \pm 1.37)$. 
Effect of geographical directions, ... of Mediterranean fruit fly, Ceratitis capitata (Wiedemann, 1824) in citrus orchards

Table 3: Results of simple analysis of variance of data of male and female of the Mediterranean fruit fly, Ceratitis capitata per month, separately

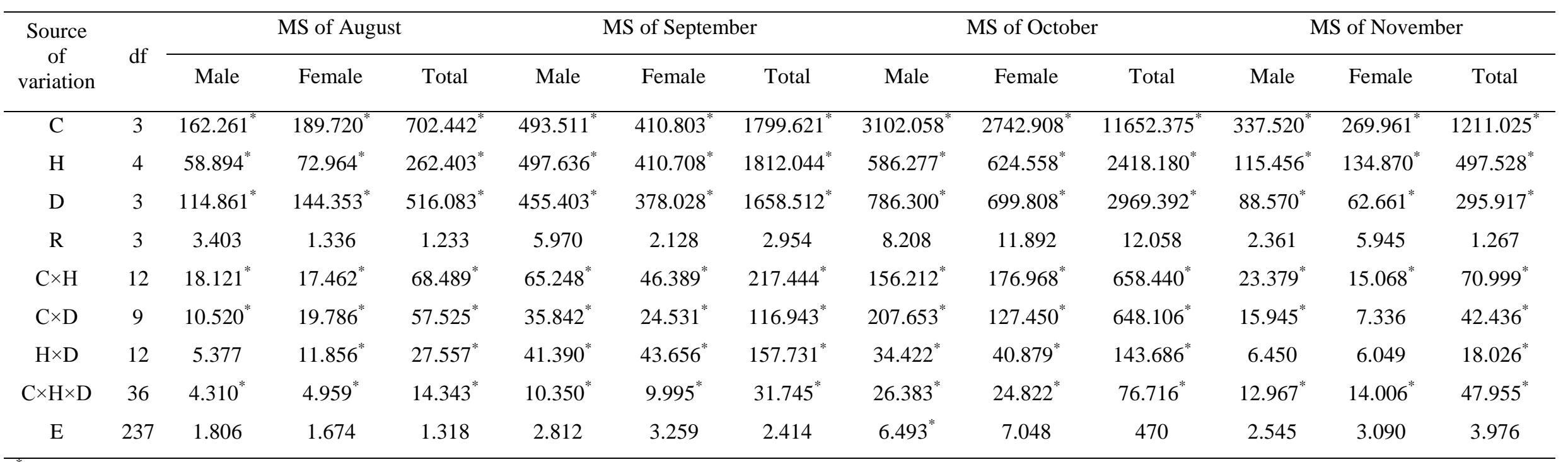

* Significant at \%5; C = Color; $\mathrm{H}=$ Height; $\mathrm{D}=$ Direction; $\mathrm{R}=$ Replicate; $\mathrm{E}=$ Error; MS = Mean Square

Table 4: Mean results of capturing of the Mediterranean fruit fly, Ceratitis capitata by sex in different months and different directions using yellow cards

\begin{tabular}{|c|c|c|c|c|c|c|c|c|c|c|c|c|}
\hline \multirow[t]{2}{*}{ Direction } & \multicolumn{3}{|c|}{ MS of August } & \multicolumn{3}{|c|}{ MS of September } & \multicolumn{3}{|c|}{ MS of October } & \multicolumn{3}{|c|}{ MS of November } \\
\hline & Male & Female & Total & Male & Female & Total & Male & Female & Total & Male & Female & Total \\
\hline North & $1.24 \pm 0.07^{\mathrm{c}}$ & $1.07 \pm 0.09^{\mathrm{c}}$ & $2.31 \pm 0.18^{\mathrm{c}}$ & $2.69 \pm 0.28^{\mathrm{c}}$ & $2.62 \pm 0.18^{\mathrm{c}}$ & $5.31 \pm 0.38^{\mathrm{c}}$ & $5.31 \pm 0.32^{\mathrm{c}}$ & $5.00 \pm 0.25^{b}$ & $10.31 \pm 0.56^{\mathrm{c}}$ & $2.99 \pm 0.16^{\mathrm{b}}$ & $2.54 \pm 0.11^{\mathrm{c}}$ & $5.52 \pm 0.28^{\mathrm{c}}$ \\
\hline South & $3.72 \pm 0.18^{\mathrm{a}}$ & $3.26 \pm 0.12^{\mathrm{a}}$ & $6.99 \pm 0.31^{\mathrm{a}}$ & $6.54 \pm 0.17^{\mathrm{a}}$ & $6.42 \pm 0.32^{\mathrm{a}}$ & $12.96 \pm 0.50^{\mathrm{a}}$ & $10.19 \pm 0.92^{\mathrm{a}}$ & $9.66 \pm 1.02^{\mathrm{a}}$ & $19.85 \pm 1.93^{\mathrm{a}}$ & $4.61 \pm 0.33^{\mathrm{a}}$ & $4.26 \pm 0.28^{\mathrm{a}}$ & $8.87 \pm 0.60^{a}$ \\
\hline East & $2.97 \pm 0.21^{\mathrm{b}}$ & $2.79 \pm 0.26^{\mathrm{b}}$ & $5.76 \pm 0.46^{\mathrm{b}}$ & $6.16 \pm 0.23^{\mathrm{a}}$ & $5.52 \pm 0.12^{b}$ & $11.69 \pm 0.34^{\mathrm{b}}$ & $9.36 \pm 0.79^{b}$ & $8.94 \pm 0.98^{\mathrm{a}}$ & $18.30 \pm 1.76^{\mathrm{b}}$ & $4.27 \pm 0.42^{\mathrm{a}}$ & $3.65 \pm 0.20^{b}$ & $7.92 \pm 0.60^{b}$ \\
\hline West & $0.95 \pm 0.19^{c}$ & $0.89 \pm 0.17^{\mathrm{c}}$ & $1.84 \pm 0.35^{\mathrm{d}}$ & $1.85 \pm 0.19^{\mathrm{d}}$ & $1.96 \pm 0.05^{\mathrm{d}}$ & $3.81 \pm 0.25^{\mathrm{d}}$ & $3.69 \pm 0.19^{\mathrm{d}}$ & $3.60 \pm 0.23^{c}$ & $7.29 \pm 0.41^{\mathrm{d}}$ & $2.39 \pm 0.13^{\mathrm{c}}$ & $2.44 \pm 0.12^{\mathrm{c}}$ & $4.82 \pm 0.24^{\mathrm{d}}$ \\
\hline
\end{tabular}

* Similar letter in each column show no significant difference. 
Amir Hossein TOORANI and Habib ABBASIPOUR

Table 5: Mean results of capturing of the Mediterranean fruit fly, Ceratitis capitata by sex in different months and in four kinds of yellow cards

\begin{tabular}{|c|c|c|c|c|c|c|c|c|c|c|c|c|}
\hline \multirow[t]{2}{*}{ Color } & \multicolumn{3}{|c|}{ MS of August } & \multicolumn{3}{|c|}{ MS of September } & \multicolumn{3}{|c|}{ MS of October } & \multicolumn{3}{|c|}{ MS of November } \\
\hline & Male & Female & Total & Male & Female & Total & Male & Female & Total & Male & Female & Total \\
\hline $\begin{array}{c}\text { Fluorescent } \\
\text { Y }\end{array}$ & $4.10 \pm 0.27^{\mathrm{a}}$ & $3.67 \pm 0.19^{\mathrm{a}}$ & $7.77 \pm 0.48^{\mathrm{a}}$ & $6.57 \pm 0.62^{\mathrm{a}}$ & $6.01 \pm 0.79^{\mathrm{a}}$ & $12.59 \pm 1.41^{\mathrm{a}}$ & $14.91 \pm 1.12^{\mathrm{a}}$ & $13.64 \pm 0.88^{\mathrm{a}}$ & $28.55 \pm 2.01^{\mathrm{a}}$ & $4.71 \pm 0.41^{\mathrm{a}}$ & $4.24 \pm 0.33^{\mathrm{ab}}$ & $8.95 \pm 0.76^{\mathrm{a}}$ \\
\hline Lemon Y & $2.80 \pm 0.14^{\mathrm{b}}$ & $2.64 \pm 0.22^{\mathrm{b}}$ & $5.44 \pm 0.34^{\mathrm{b}}$ & $6.22 \pm 0.39^{\mathrm{a}}$ & $5.97 \pm 0.40^{\mathrm{a}}$ & $12.20 \pm 0.77^{\mathrm{a}}$ & $9.35 \pm 1.21^{\mathrm{b}}$ & $9.67 \pm 1.11^{\mathrm{b}}$ & $19.02 \pm 2.35^{\mathrm{b}}$ & $4.84 \pm 0.38^{\mathrm{a}}$ & $4.41 \pm 0.29^{\mathrm{a}}$ & $9.25 \pm 0.67^{\mathrm{a}}$ \\
\hline Amber Y & $0.65 \pm 0.05^{\mathrm{d}}$ & $0.51 \pm 0.07^{\mathrm{d}}$ & $1.16 \pm 0.13^{\mathrm{d}}$ & $1.52 \pm 0.19^{\mathrm{c}}$ & $1.39 \pm 0.09^{\mathrm{c}}$ & $2.91 \pm 0.31^{\mathrm{c}}$ & $1.40 \pm 0.16^{\mathrm{d}}$ & $1.36 \pm 0.18^{\mathrm{d}}$ & $2.76 \pm 0.32^{\mathrm{d}}$ & $0.51 \pm 0.07^{\mathrm{c}}$ & $0.50 \pm 0.09^{\mathrm{c}}$ & $1.01 \pm 0.18^{\mathrm{c}}$ \\
\hline $\mathrm{Y}$ & $1.33 \pm 0.10^{\mathrm{c}}$ & $1.19 \pm 0.19^{c}$ & $2.52 \pm 0.28^{\mathrm{c}}$ & $2.91 \pm 0.41^{\mathrm{b}}$ & $3.16 \pm 0.21^{\mathrm{b}}$ & $6.07 \pm 0.23^{\mathrm{b}}$ & $2.89 \pm 0.20^{\mathrm{c}}$ & $2.52 \pm 0.34^{\mathrm{c}}$ & $5.41 \pm 0.53^{c}$ & $4.20 \pm 0.73^{\mathrm{b}}$ & $3.74 \pm 0.22^{\mathrm{b}}$ & $7.94 \pm 0.96^{\mathrm{b}}$ \\
\hline
\end{tabular}

${ }^{*}$ Similar letter in each column show no significant difference. Y: Yellow

Table 6: Mean results of capturing of the Mediterranean fruit fly, Ceratitis capitata by sex in different months and different heights using yellow cards

\begin{tabular}{|c|c|c|c|c|c|c|c|c|c|c|c|c|}
\hline \multirow{2}{*}{$\begin{array}{l}\text { Height } \\
\text { (meter) }\end{array}$} & \multicolumn{3}{|c|}{ MS of August } & \multicolumn{3}{|c|}{ MS of September } & \multicolumn{3}{|c|}{ MS of October } & \multicolumn{3}{|c|}{ MS of November } \\
\hline & Male & Female & Total & Male & Female & Total & Male & Female & Total & Male & Female & Total \\
\hline 1 & $3.12 \pm 0.28^{\mathrm{c}}$ & $2.80 \pm 0.34^{\mathrm{c}}$ & $5.93 \pm 0.61^{d}$ & $1.48 \pm 0.12^{\mathrm{c}}$ & $1.41 \pm 0.35^{\mathrm{c}}$ & $2.89 \pm 0.46^{\mathrm{c}}$ & $2.39 \pm 0.19^{c}$ & $2.28 \pm 0.57^{\mathrm{c}}$ & $4.68 \pm 0.78^{d}$ & $5.50 \pm 0.81^{\mathrm{c}}$ & $6.19 \pm 1.03^{\mathrm{c}}$ & $11.69 \pm 1.86^{\mathrm{c}}$ \\
\hline 1.5 & $6.54 \pm 0.70^{\mathrm{a}}$ & $6.18 \pm 0.62^{\mathrm{a}}$ & $12.72 \pm 1.133^{\mathrm{a}}$ & $3.22 \pm 0.45^{\mathrm{a}}$ & $2.78 \pm 0.29^{\mathrm{a}}$ & $6.04 \pm 0.72^{\mathrm{a}}$ & $7.52 \pm 1.13^{\mathrm{a}}$ & $7.10 \pm 1.22^{\mathrm{a}}$ & $14.62 \pm 2.35^{\mathrm{a}}$ & $10.52 \pm 1.16^{\mathrm{a}}$ & $10.81 \pm 1.37^{\mathrm{a}}$ & $21.33 \pm 2.54^{\mathrm{a}}$ \\
\hline 2 & $6.27 \pm 0.71^{\mathrm{a}}$ & $6.05 \pm 0.88^{\mathrm{a}}$ & $12.31 \pm 1.61^{\mathrm{b}}$ & $3.12 \pm 0.19^{\mathrm{a}}$ & $2.92 \pm 0.21^{\mathrm{a}}$ & $6.00 \pm 0.38^{\mathrm{a}}$ & $7.06 \pm 0.92^{\mathrm{a}}$ & $6.58 \pm 0.64^{\mathrm{a}}$ & $13.64 \pm 1.58^{\mathrm{b}}$ & $9.50 \pm 1.01^{b}$ & $9.62 \pm 1.20^{\mathrm{b}}$ & $19.12 \pm 2.19^{b}$ \\
\hline 2.5 & $3.66 \pm 0.09^{b}$ & $3.37 \pm 0.41^{\mathrm{b}}$ & $7.03 \pm 0.51^{\mathrm{c}}$ & $2.52 \pm 0.19^{\mathrm{b}}$ & $2.25 \pm 0.41^{\mathrm{b}}$ & $4.77 \pm 0.62^{b}$ & $3.12 \pm 0.19^{\mathrm{b}}$ & $3.08 \pm 0.40^{\mathrm{b}}$ & $6.20 \pm 0.61^{c}$ & $5.50 \pm 0.55^{\mathrm{c}}$ & $5.64 \pm 0.62^{c}$ & $11.14 \pm 1.17^{\mathrm{c}}$ \\
\hline 3 & $1.96 \pm 0.18^{\mathrm{d}}$ & $1.80 \pm 0.13^{\mathrm{d}}$ & $3.75 \pm 0.33^{\mathrm{e}}$ & $0.77 \pm 0.03^{\mathrm{d}}$ & $0.66 \pm 0.13^{\mathrm{d}}$ & $1.43 \pm 0.15^{\mathrm{d}}$ & $1.46 \pm 0.78^{\mathrm{d}}$ & $1.62 \pm 0.53^{\mathrm{d}}$ & $3.08 \pm 1.33^{\mathrm{e}}$ & $2.98 \pm 0.56^{\mathrm{d}}$ & $3.42 \pm 0.72^{\mathrm{d}}$ & $6.41 \pm 1.30^{\mathrm{d}}$ \\
\hline
\end{tabular}

* Similar letter in each column show no significant difference. 


\subsection{Effect of correlation between the different colors and directions}

Due to the correlation between the color of the cards and directions, independent separation of data was performed between the different colors (Figure 2). According to the figure, the minimum and maximum amount of the whole individuals captured was obtained in amber yellow treatments and the West direction $(0.78$ $\pm 0.17)$, and chartreus yellow and south $(21.19 \pm 0.87)$, respectively.

\subsection{Effect of correlation between the different colors and heights}

According to the correlation between color and height results, independent separation of data was performed between the different colors (Figure 3). Based on the results in all the colors, the number of male, female and total captures in the height of $1.5 \mathrm{~m}$ was more than any other height, except for the male treatment of fluorescent yellow and male, female and total individuals in yellow treatments. The least amount of capture was observed in females in the treatment of amber yellow and the height of $3 \mathrm{~m}(0.64 \pm 0.10)$, and the highest number of captures in males in the treatment of fluorescent yellow and the height of $2 \mathrm{~m}(11.34 \pm$ 2.16), respectively.
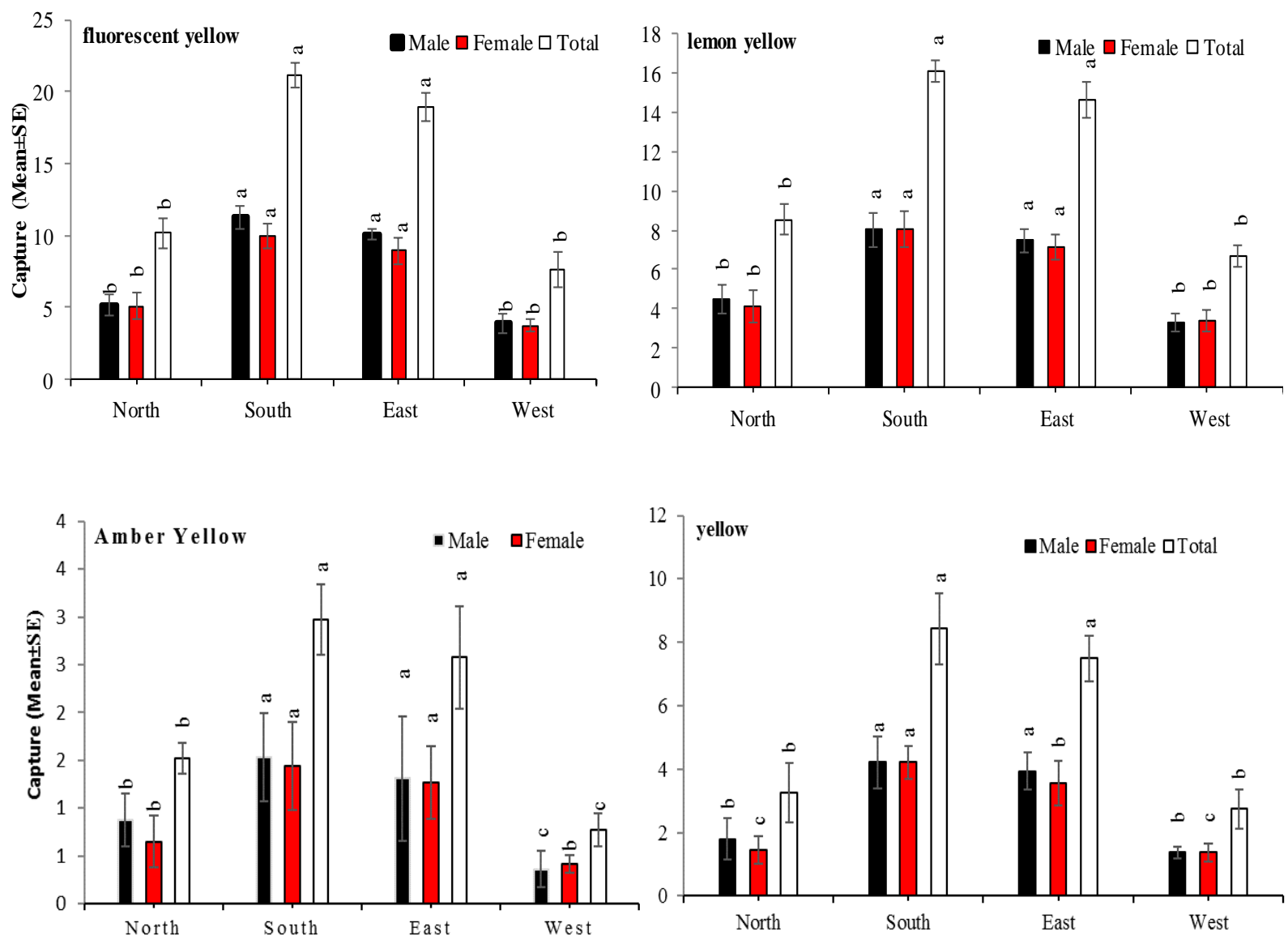

Figure 2: Capturing number of the Mediterranean fruit fly, Ceratitis capitata by sex in different directions and different kinds of yellow cards. The dissimilar letters on each column indicate significant differences 

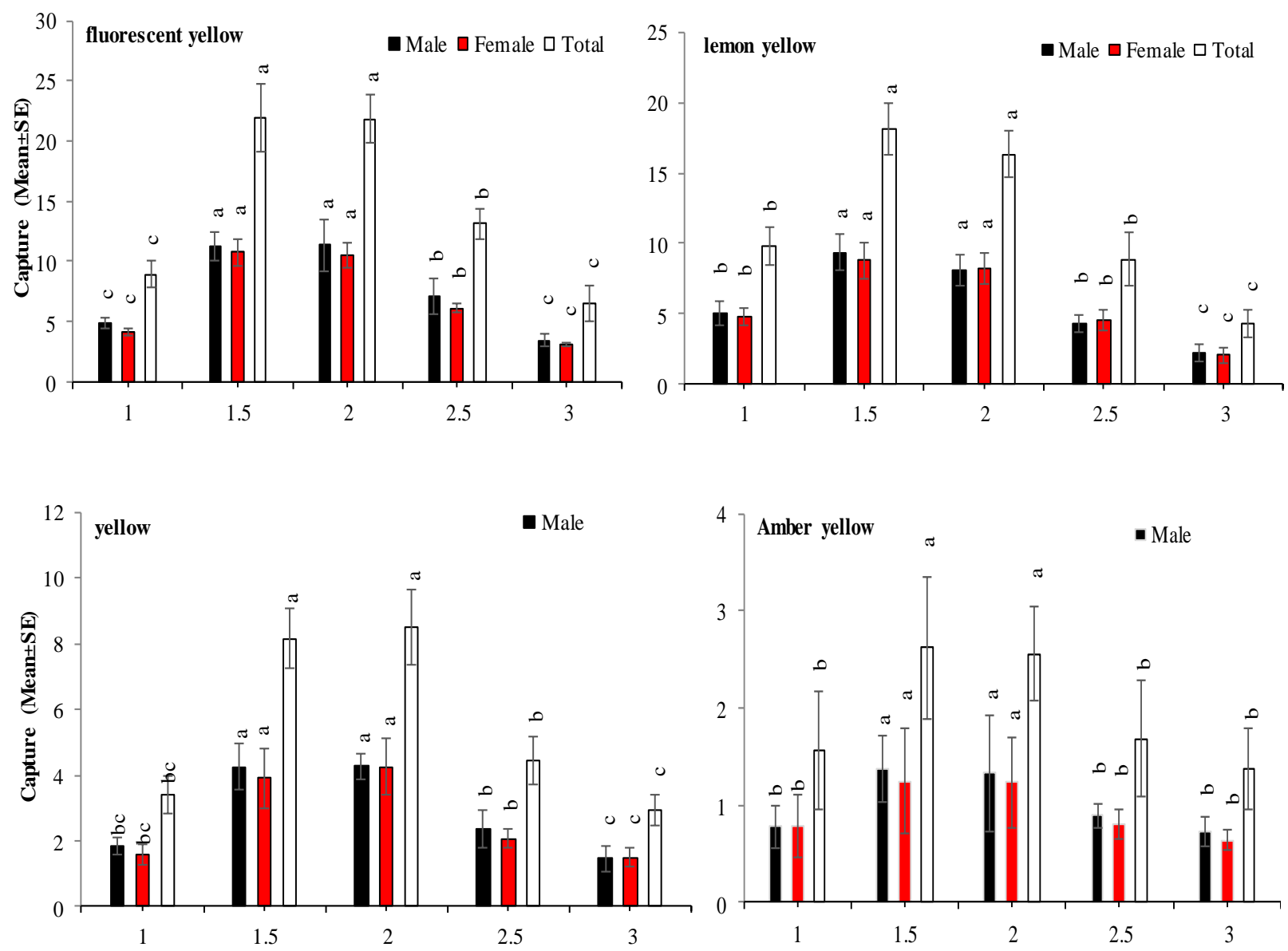

Figure 3: Capturing number of the Mediterranean fruit fly, Ceratitis capitata by sex in different heights and different kinds of yellow cards. The dissimilar letters on each column indicate significant differences

\section{DISCUSSION}

In the study of Pezhman et al. (2010b), the results showed that adult insect activity in the fruit orchards has begun from the third decade of July and has continued to mid-December. The peak trapping of adult insects was observed in September and October. On the other hand, the assessment of pest seasonal fluctuations using bait attractant Ceratrap (Cera lure) with perforated Mcphail trap showed that this insect has three population peaks in the region. The most important density was in September and October, which coincided with tangerine color change (premature Japanese and Satsuma Figures) and the citrus fruit harvest time (Mafi Pashakolaei et al., 2010). The study results showed that the Mediterranean fruit fly population declines with cold weather and its immature stages growth period (embryonic, larval and pupal period) becomes longer (Vargas et al., 1983). Therefore, the greatest damage occurred in the orchards of figs in the Island of Kauai in the Hawaiian Islands, the environmental conditions of which were ideal for pest activity (Vargas et al., 1983).
A study about Mediterranean fruit fly in Montenegro in 2003 showed that fly populations reached its maximum during September and October. Also in 2004, the maximum population found from late October to midNovember (Radonjić, 2006). In this study, the most capture of Mediterranean fruit fly was in October, which is consistent with the results of other researchers (Darwish, 2014; Pezhman et al., 2010b; Rigamonti, 2004; Papadopoulos et al., 2001).

According to tests conducted over the 2002-2003 crop years, the colored cards (yellow, green, red, blue, white and black) were installed on bases in four heights $(0.25$, $0.5,0.75$ and $1 \mathrm{~m}$ ) on the sidelines of sugar beet farm. In the first year, the yellow color had the maximum attraction of sugar beet flea beetle, Chaetocnema tibialis Illiger, 1807 (Col.: Chrysomelidae), and in the second year, the yellow cards with two spectrums of lemon yellow and deep yellow were compared, which the highest attraction of sugar beet flea beetle was for lemon yellow spectrum and at the height of $0.25 \mathrm{~m}$ 
(Haghshenas et al., 1998). The results of research on the Mexican fruit fly, Anastrepha ludens Loew, 1873 showed that attract the fluorescent yellow color had more fly attraction than white (Velasco-Pascual \& Enkerlin, 1980). Other species of fruit flies such as South American fruit fly, Anastrepha fraterculus (Wied., 1830) (Cytrynowicz et al., 1982), cherry fruit fly, Rhagoletis cingulata (Loew, 1862) (Frick et al., 1954), Apple fruit fly, Rhagoletis pomonella (Walsh, 1867) (Prokopy, 1968), European Cherry fruit fly, Rhagoletis cerasi (L., 1758) (Prokopy \& Boller, 1971), Walnut husk fly, Rhagoletis completa (Cresson, 1929) (RiedL \& Hislop, 1985), olive fruit fly, Bactrocera oleae (Rossi, 1790) (Prokopy et al., 1975), Queensland fruit fly, Bactrocera tryoni (Froggatt, 1897) and similar species $B$. neohumeralis (Hardy, 1951) and $B$. cacuminatus (Hering, 1941) (Hill \& Hooper, 1984) and the Mediterranean fruit fly, Ceratitis capitata (Wiedemann, 1824) (Prokopy \& Economopoulos, 1976) had the most attraction to yellow or fluorescent yellow (520-540 nm peak reflectivity), and generally flies of the family Tephritidae had most tendency to yellow and fluorescent yellow (Prokopy, 1972). In our study, fluorescent yellow had the most fly trapping, and given that among the colors tested.

A comparison of the different heights of the trap installation showed that a height of $1.5 \mathrm{~m}$ had a better efficiency for capturing Mediterranean fruit fly. The results obtained in this study are consistent with the results of previous researches on the height of the trap for pomegranate fruit moth (Jafari-Nodooshan, 2003), quince moth (Kermani, 2010) and codling moth (Barrett, 1995). The results of tests on the Mexican fruit fly, Anastrepha ludens showed that these flies at heights of 1 and $2 \mathrm{~m}$ from ground level, have been attracted to traps more than the height of 0.1 or $3 \mathrm{~m}$. The results also showed that more flies were captured in the north than in the south, while the flies attracted to East and West were not significantly different (Robacker et al., 1990). Suitable height for trapping citrus whitefly, Parabemisia myricae (Kuwana, 1927) has been reported at $76 \mathrm{~cm}$ from the ground (Meyerdirk \& Moreno, 1984). Moreover, height of $7.2 \mathrm{~m}$ and the southern position of citrus trees was a convenient location for tracking citrus thrips, Scirtothrips citri (Moulton, 1909) (Beavers et al., 1971). Whereas, in pear orchards, installation of the traps at a height of $1.2-1.8 \mathrm{~m}$ of south side of the trees had more correlation with infestation of trees with egg and nymph of pear psylla, Psylla pyricola (Foerster, 1848) (Adams \& Los, 1989). The investigation conducted by Seyedoleslami et al. (2003) on Pistachio psylla, Agonoscena pistaciae Burckhardt and Lauterer, 1989 revealed a significant difference for different directions in trapping adult insects and egg density. The results showed that for forecasting of the density of eggs and wingless nymphs, the traps can be placed on each of the two heights and four geographical directions, except in the low East, and preferably in the South or high East (Seyedoleslami et al., 2003). In evaluating the effect of geographical direction and height on the capture of adult Pistachio psylla, no significant difference was seen, although capture density was higher on the southern side of the tree (Emami, 1995). A research conducted in three consecutive years 2013 - 2015 in olive gardens, to determine the best height and the best geographical direction for the installation of color cards, showed that the heights of 1 and $3 \mathrm{~m}$ and the south direction on average during the three years, had the biggest number of captured olive fly, B. oleae (Toorani et al., 2016). Capture of fruit flies by various traps is influenced in addition to the shape, size, trap color and climatic factors, by the installation direction and height from the ground level (Katsoyannos, 1987). In tests of trapping Mediterranean fruit flies performed in different heights $(0.3,0.60,1.82$ and $4.57 \mathrm{~m})$, by plastic traps baited with Trimedlure in lands with vegetation including species of tropical and subtropical fruits, showed that height of $4.57 \mathrm{~m}$ had the highest captured flies (Holbrook \& Fujimoro, 1969).

There are many examples demonstrating that the optimum height for catching flies depends on tree size. In the case of tall plants, captures tend to be greater at intermediate-upper heights as reported in the following examples: $4 \mathrm{~m}$ height of $8 \mathrm{~m}$ tall mango trees for Bactrocera dorsalis (Hendel, 1912) (Ye et al., 2012), 3 $\mathrm{m}$ in $10 \mathrm{~m}$ tall guava trees (Siddiqui et al., 2003) for the peach fruit fly, Bactrocera zonata (Saunders, 1841), 5 $\mathrm{m}$ height of $8 \mathrm{~m}$ tall mango trees for several Anastrepha species (Aluja et al., 1989), $5 \mathrm{~m}$ in field trials conducted with diverse tall vegetation (including many species of tropical and subtropical fruits and truck crops) for $C$. capitata (Holbrook \& Fujimoro, 1969), and $4.5 \mathrm{~m}$ in $4.65 \mathrm{~m}$ tall cherry trees for the cherry fruit fly, Rhagoletis cingulata (Pelz-Stelinski et al., 2006). Optimum trapping heights for smaller sized plants with fruits near the ground tend to be at low heights, typically below the half-height of the plant. For example, traps near the ground (from $3 \mathrm{~cm}$ to $1.8 \mathrm{~m}$ ) were more effective than traps placed at 3 and $5 \mathrm{~m}$ for the melon fly, Bactrocera cucurbitae (Coquillett, 1849) (Holbrook \& Fujimoro, 1969) as this species usually attacks low or creeper plants. For small trees, from 1 to $3 \mathrm{~m}$, such as peaches or citrus in the Mediterranean Basin, maximum catch is obtained around $1.5 \mathrm{~m}$ height as shown for B. zonata in peach trees (El-Gendy, 2012). However, Hooper and Drew (1979) observed no effect of height on captures of Bactrocera tryoni, $B$. neohumeralis, $B$. cacuminatus and $B$. endiandrae (Perkins \& May, 1949) with cue-lure or methyl eugenol within the range of 0.1-3.6 m above ground in citrus orchards with trees averaging $4.6 \mathrm{~m}$ in height or in suburban gardens. This absence of height effect could 
be explained by the high attractant power of male lures that can reduce the importance of other variables, such as trap height.

\section{CONCLUSION}

Given the high importance of the Mediterranean fruit fly in citrus orchards of Mazandaran province (Iran), and in accordance with the tests done, the fluorescent yellow in heights 1.5 and $2 \mathrm{~m}$ and in the south, can have the greatest fly trapping, and experts and gardeners can use this information to determine the best time to control. Tests carried out showed that the colored cards have the ability to control the pest population and considerable damage has not been observed.

\section{ACKNOWLEDGEMENTS}

The authors are thankful to officials of spectroscopy laboratory, Institute of Nanotechnology, Sharif University of Technology and Department of
Chemistry, to assist in measuring and calculating the wavelength of the used colors.

\section{REFERENCES}

Adams, R.G., \& Los, L.M. (1989). Use of sticky traps and limb jarring to aid in pest management decisions for summer populations of pear psylla (Homoptera: Psyllidae) in Connecticut. Journal of Economic Entomology, 82, 1448-1454. doi:10.1093/jee/82.5.1448

Aluja, M., Cabrera, M., Guillen, J., Celedonio, H., \& Agora, F. (1989). Behaviour of Anastrepha ludens, A. obliqua and A. serpentina (Diptera: Tephritidae) on a wild mango tree (Mangifera indica) harbouring three McPhail traps. International Journal of Tropical Insect Science, 10, 309-318. doi:10.1017/S1742758400003544

APHIS. (1992). Risk assessment, Mediterranean fruit fly. Washington D.C.: Planning and Risk Analysis Systems. Policy and Program Development. Animal and Plant Health Inspection Service USDA.

Barrett, B.A. (1995). Effect of synthetic pheromone permeation on captures of male codling moth (Lepidoptera: Tortricidae) in pheromone and virgin female moth-baited traps at different tree heights in small orchard blocks. Environmental Entomology, 24, 1201-1206. doi:10.1093/ee/24.5.1201

Beavers, J.B., Shaw, J.G., \& Hampton, R.B. (1971). Color height and preference of the citrus thrips in a navel orange grove. Journal of Economic Entomology, 64, 1112-1113. doi:10.1093/jee/64.5.1112

Carey, J.R. (1996). The Incipient Mediterranean fruit fly Population in California: Implications for Invasion Biology. Ecology, 77, 1690-1697. doi: $10.2307 / 2265775$
Cayol, J.P., Causse, R., Louis, C., \& Barthes, J. (1994). Medfly Ceratitis capitata Wiedemann (Dipt.: Trypetidae) as a rot vector in laboratory conditions. Journal of Applied Entomology, 117(4), 338-343. doi:10.1111/j.1439-0418.1994.tb00744.x

Cohen, H., \& Yuval, B. (2000). Perimeter trapping strategy to reduce Mediterranean fruit fly (Diptera: Tephritidae) damage on different host species in Israel. Journal of Economic Entomology, 93(3), 721-725. doi:10.1603/0022-0493-93.3.721

Cytrynowicz, M., Morgante, J.S. \& De Souza, H.M.L. (1982). Visual responses of South American fruit flies, Anastrepha fraterculus, and Mediterranean fruit flies, Ceratitis capitata, to colored rectangles and spheres. Environmental Entomology, 11, 12021210. doi:10.1093/ee/11.6.1202

Darwish, A.A.E. (2014). Population density, diurnal activity and effect of trap height on capturing of peach fruit fly, Bactrocera zonata (saunders) and mediterranean fruit fly, Ceratitis capitata (wiedemann) in guava orchards at nubaria region, Egypt. Journal of Plant Protection and Pathology, Mansoura University, 5(1), 89-98.

El-Gendy, I.R. (2012). Elevation of attraction efficiency of Jackson trap on peach fruit fly, Bactrocera zonata (Saunders). International Journal of Agricultural Research, 7, 223-230. doi:10.3923/ijar.2012.223.230

Emami, Y. (1995). Study of geographical directions on the pistachio psylla attracted to sticky yellow traps. Proceeding of $12^{\text {th }}$ Iranian Plant Protection 
Effect of geographical directions, ... of Mediterranean fruit fly, Ceratitis capitata (Wiedemann, 1824) in citrus orchards

Congress, Faculty of Agriculture, University of Tehran, Karaj, Iran, p 486.

Enkerlin, W., \& Mumford, J. (1997). Economic Evaluation of Three Alternative Methods for Control of the Mediterranean fruit fly (Diptera: Tephritidae) in Israel, Palestinian Territories, and Jordan. Journal of Economic Entomology, 90, 1066-1072. doi:10.1093/jee/90.5.1066

Fimiani, P. (1989). Pest status; Mediterranean region. In: Robinson AS, Hooper G, eds. Fruit Flies; Their Biology, Natural Enemies and Control. World Crop Pests, 3(A), 37-50.

Frick, K.E., Simkover, H.G., \& Telford, H.S. (1954). Bionomics of the cherry fruit fly in eastern Washington. The Agricultural Experiment Station Technical Bulletin Series, 13, 1-66.

Gholamian, E., Aghajanzadeh, S., \& Goleyn, B. (2013). Monitoring the Mediterranean fruit fly, Ceratitis capitata (Wiedemann) (Dip.: Tephritidae) in citrus orchards in west of Mazandaran and East of Guilan provinces. Plant Pests Research, 3(1), 59-67. (In Persian with English summary)

Haghshenas, A.R., Zarabi, M., \& Afioni, D. (2008). Investigation on sticky colour traps on attraction of sugar beet flea beetle, Chaetocnema tibialis I1 1iger (Col., Chrysomelidae) in Esfahan Province. Journal of Sugarbeet, 24(1), 97-105. (In Persian with English summary)

Hashem, A.G., Harris, E.J., \& Saafan, M.H. (1987). Efficiency of different types of lure traps for detecting and monitoring the Mediterranean fruit fly, Ceratitis capitata (Wied.) in Egypt. Zagazig Journal of Agricultural Research, 14(1), 797-814.

Hill, A.R., \& Hooper, G.H.S. (1984). Attractiveness of various colors to Australian tephritid fruit flies in the field. Entomologia Experimentalis et Applicata, 35, 119-128. doi:10.1111/j.15707458.1984.tb03371.x

Holbrook, F.R, \& Fujimoro, M.S. (1969). Mediterranean fruit flies and melon flies trapped at various heights with synthetic lures. Journal of Economic Entomology, 62, 962-963. doi:10.1093/jee/62.4.962

Hooper, G.H.S, \& Drew, R.A.I. (1979). Effect of height of trap on capture of tephritid fruit flies with cue lure and methyl eugenol in different environments. Environmental Entomology, 8, 786-788. doi:10.1093/ee/8.5.786

Jafari-Nodooshan, A. (2003). Investigation on the possibility of using the natural sex pheromone in flight peak determination and reduction of pomegranate fruit moth damage, Final report of research project, Agricultural and Natural Resources Research Center of Yazd, 40 pp. (In Persian with English summary)

Jang, E.B. (2007). Fruit flies and their impact on agriculture in Hawaii. Available: http://scholarspace.manoa. hawaii.edu/handle/10125/1297. Accessed 21 November 2011.

Katsoyannos, B.I. (1987). Response to shape, size and color. pp. 307-324 in Robinson, A.S. \& Hooper, G. (Eds.) World crop pests: fruit flies - their biology, natural enemies and control. Vol. 3A, 372 pp. Elsevier Science Publishers.

Katsoyannos, B.I., Heath, R.R., Papadopoulos, N.T., Epsky, N.D., \& Hendrichs, J. (1999). Field evaluation of Mediterranean fruit fly (Diptera: Tephritidae) female selective attractants for use in monitoring programs. Journal of Economic Entomology, $\quad$ 92(3), 583-589. doi:10.1093/jee/92.3.583

Kermani, P. (2010). Evaluation of the sex pheromone and monitoring of quince moth, Euzophera bigella Zeller (Lep.: Pyralidae) in quince orchards of Esfahan, MSc. thesis, Arak Islamic Azad University, 77 pp. (In Persian with English summary)

Mafi Pashakolaei, SH.A., Barari, H., \& Norakizadeh, M. (2010). Investigation on the efficacy of different traps and attractant compounds on attraction and monitoring of medfly, Ceratitis capitata Wied in Mazandaran province. 19th Iranian Plant Protection Congress, 31 July - 3 August 2010, Tehran, Iran, p 199.

Meyerdirk, D.E., \& Moreno, D.S. (1984). Flight behavior and color-trap preference of Parabemisia myricae (Kuwana) (Homoptera: Aleyrodidae) in a citrus orchard. Environmental Entomology, 13, 167-170. doi:10.1093/ee/13.1.167

Mirsardoo, S., Mafi-Pashakolaei, S.A., \& Barari, H. (2010). Preliminary investigation on the geographical distribution of Mediterranean fruit fly, Ceratitis capitata (Wiedemann) (Dip.: Tephritidae) in Mazandaran province, Iran. Journal of Entomology, 2, 143-154. (In Persian with English summary)

Papadopoulos, N.T., Katsoyannos, B.I., Carey, J.R., \& Kouloussis, N.A. (2001). Seasonal and annual occurrence of the Mediterranean fruit fly, (Diptera: Tephritidae) in northern, Greece. Annales of Entomological Society of America, 94, 41-50. doi:10.1603/00138746(2001)094[0041:SAAOOT]2.0.CO;2 
Pelz-Stelinski, K.S, Gut, L.J., \& Isaacs, R. (2006). Vertical position of traps influences captures of eastern cherry fruit fly (Diptera: Tephritidae). Florida Entomologists, 89, 80-82. doi:10.1653/00154040(2006)89[80:VPOTIC]2.0.CO;2

Pezhman, H., Ostovan, H., Kamali, K., \& Rezaei, V. (2010a). Evaluation of various traps and attractants for mass trapping the Mediterranean fruit fly, Ceratitis capitata (Diptera: Tephritidae), in a mixed-fruit orchard in Shiraz. 19th Iranian Plant Protection Congress, 31 July - 3 August 2010, Tehran, Iran, p 486.

Pezhman, H., Ostovan, H., Kamali, K., \& Rezaei, V. (2010b). Host ranges and biology of the Mediterranean fruit fly, Ceratitis capitata (Diptera: Tephritidae), in Shiraz orchards. 19th Iranian Plant Protection Congress, 31 July - 3 August 2010, Tehran, Iran, p 580.

Prokopy, R.J. (1968). Visual responses of apple maggot flies, Rhagoletis pomonella (Diptera: Tephritidae): orchard studies. Entomologia Experimentalis et Applicata, $\quad 11, \quad 403-422 . \quad$ doi:10.1111/j.15707458.1968.tb02070.x

Prokopy, R.J., \& Boller, E.F. (1971). Response of European cherry fruit flies to colored rectangles. Journal of Economic Entomology, 64, 1444-1447. doi:10.1093/jee/64.6.1444

Prokopy, R.J., Economopoulos, A.P., \& Mc-Fadden, M.W. (1975). Attraction of wild and laboratory cultured Dacus oleae flies to small rectangles of different hues, shades and tints. Entomologia Experimentalis et Applicata, 18, 141-152. doi:10.1111/j.1570-7458.1975.tb02364.x

Prokopy, R.J., \& Economopoulos, A.P. (1976). Color responses of Ceratitis capitata flies. Journal of Applied Entomology, 80, 434-437. doi:10.1111/j.1439-0418.1976.tb03346.x

Prokopy, R.J. (1972). Response of apple maggot flies to rectangles of different colors and shades. Environmental Entomology, 1, 720-726. doi:10.1093/ee/1.6.720

Radonjić, S. (2006). The Mediterranean fruit fly, Ceratitis capitata (Wiedemann) (Diptera: Tephritidae), a new pest in Montenegro. IOBC/WPRS Bulletin, 29(3), 217-224.

Riedl, H., \& Hislop, R. (1985). Visual attraction of the walnut husk fly (Diptera: Tephritidae) to color rectangles and spheres. Environmental Entomology, 14, 810-814. doi:10.1093/ee/14.6.810

Rigamonti, I.E. (2004). Contributions to the knowledge of Ceratitis capitata Wied. (Diptera,Tephritidae) in
Northern Italy. II. Overwintering in Lombardy. Bolletino di Zoologia agraria e di Bachicoltura, 36(1), 101-116.

Robacker, D.C., Moreno, D.S., \& Wolfenbarger, D.A. (1990). Effects of trap color, height, and placement around trees on capture of Mexican fruit flies (Diptera: Tephritidae). Journal of Economic Entomology, 83(2), 412-419. doi:10.1093/jee/83.2.412

Sabzevari, A., \& Jafari, M.E. (1991). Bio-ecological studies and eradication of the pest in Mazandaran «The last infested area in Iran». Bulletin of Plants Pest and Diseases of Research Institute, 38 p. (In Persian with English summary)

Seyedoleslami, H., Hadian, A.R., \& Rezai, A. (2003). Estimation of Population Density of First and Second Instar Nymphs of Pistachio Psylla, Agonoscena pistaciae (Hom.: Psyllidae) from Adult Psylla Capture on Yellow Sticky Traps. Journal of Agricultural Science Technology and Natural Research, 7(1), 223-232. (In Persian with English summary)

Siddiqui, Q.H, Ahmad, D, Shad Rashdi, SMM, Niazi, S. (2003). Effect of time of the day and trap height on the catches of peach/guava fruit flies Bactrocea zonata (Saunders) through male annihilation technique. Asian Journal of Plant Science, 2, 228232. doi:10.3923/ajps.2003.228.232

Szyniszewska, A.M., \& Tatem, A.J. (2014). Global Assessment of Seasonal Potential Distribution of Mediterranean Fruit Fly, Ceratitis capitata (Diptera: Tephritidae). PLOS one, 9(11), e111582. doi:10.1371/journal.pone.0111582

Toorani, A.H., Heydari, S., \& Abbasipour, H. (2016). Determination of direction and height suitable for installation of yellow sticky traps along with sex pheromone designed to capture the olive fruit fly, Bactrocera oleae (Rossi) (Dip.: Tephritidae). National Conference on Research and Technology Findings in Natural and Agricultural Ecosystems, 19 October, 2016, Tehran, Iran, P. 409.

USDA. (2012). Mediterranean fruit fly Cooperative Eradication Program. Rancho Cucamonga, San Bernardino County, California, USA, 19 p.

Vargas, R.I., Harris, E.J., \& Nishida, T. (1983). Distribution and seasonal occurrence of Ceratitis capitata (Wiedemann) (Diptera: Tephritidae) on the Island of Kauai in the Hawaiian Islands. Environmental Entomology, 12(2), 303-310. doi:10.1093/ee/12.2.303

Velasco-Pascual, H., \& Enkerlin, D. (1980). Efectos del color en trampas para captura de la mosca mexican 
Effect of geographical directions, ... of Mediterranean fruit fly, Ceratitis capitata (Wiedemann, 1824) in citrus orchards

a de la fruta Anastrepha ludens (Loew). Folia Entomologica Mexicana, 43, 11-12.

White, I.M., \& Elson-Harris, M. (1992). Fruit flies of Economic significance: Their identification and bionomics. CAB International, $601 \mathrm{p}$.
Ye, W., Li, L., Sun, L.L., Xiao, C., \& Dong, W. (2012). Daily activity and spatial distribution pattern of the oriental fruit fly, Bactrocera dorsalis (Diptera: Tephritidae) in mango orchard, Yuanjiang, Yunnan. Acta Ecologica Sinica, 32, 5199-5207. doi:10.5846/stxb201201170101 